\title{
Teachers' Art Assessment Practices: Relationship to Expertise, Experience, Beliefs and Confidence
}

\section{Christa Volk}

\author{
Introduction to the Research Problem
}

In education, theory is questionable if we lack background knowledge irom practice in the field. The purpose of this study is to examine art teachers' assessment practices and assessment criteria at elementary and secondary grade levels, so as to contribute to the theoretical bases of art education assessment in North America.

As indicated in the literature, assessment is a term that generates considerable controversy in art education. In my experience as an art education subject specialist for a large urban school district, it is a term that for some art teachers conjures visions of unpleasantness, a practice best left alone, since student art works at all grade levels are chiefly characterized by diversity-no two works are exactly alike. Yet most art teachers would agree with the notion that some form of assessment is an integral part of the art learning process for students.

\section{Background of the Problem}

Assessment draws attention to what is important or valued in the educational enterprise. Because of this attention, assessment has a pivotal psychological role in directing activities at all levels of education, from the individual student or teacher to the provincial scene. The results of assessment may be taken by those concerned as a statement on the current state of affairs of some component of education. The impact of assessment may depend on such factors as: What are perceived to be the stakes of the game for which assessment is seen to be the score? How confident are the players that the assessment is valid and reliable? Are the objectives measured by the assessment understood and accepted as being important?

Within school organizations, assessments strongly influence what, how and when content is taught to students and what students should know. Furthermore, Bullough and Goldstein (1984) say that art education is under increasing pressure to justify its social utility within the context of what is relevant and worthwhile at the school level, and the measure of that social utility may be taken through assessment.

Working Papers in Art Education 1992 


\section{The Issue of Art Âssessment}

Following a recent shift to thinking of art education as a structured discipline (Discipline-Based Art Education: Greer, 1984; Eisner, 1988; Chapman, 1978; Getty Foundation, 1985), and since instruction in art at the elementary and secondary levels has evolved to a stage where overall goals can be reasonably defined, more attention is being focused on how students' art works and learning may be adequately assessed. The essential characteristics of the disciplined-based approach to art is that instruction at any grade is not limited to producing art. Production is integrated with the learning of aesthetics, art history and art criticism. As in other school subjects where instruction reflects various disciplines, so too instruction in art can reflect several disciplines of the field.

The topic of student assessment has not been significantly controversial for art education until the recent undertaking to establish art education as a discipline started to gain ground. The profession is asking: What can be assessed? How and for what purpose? Should teachers autonomously select assessment criteria and strategies by which they may judge their students' art learning? What would be appropriate commonalities and differences in teachers' art assessment practices? Is assessment an integral part of their teaching? Is the application of criteria intended to reveal the quality of each pupil's performance irrespective of the performance of other pupils? What influences teachers' art assessment practices, and what are the pedagogical implications?

Direction from art educators such as Wilson (1986), Greer \& Hoephner (1986), Hamblen (1986, 1988), and Lehman (1986) is divided on the issue of evaluation-whether to evaluate, or how to evaluate, or criteria for evaluation. For example, Wilson advocates state-wide art testing in the United States, while Hamblen has cautioned that the imposition of a common criterion for success, and examination, will result in teaching to that criterion, and will limit students' individual creativity. However, there is an overall consensus that some form of art assessment is desirable and that in the world of education, where comparative judgements are an everyday fact of life, lack of art assessment practices constitutes a lack of responsibility on the part of those who teach art education programs.

\section{Definition of Terms}

Terms for this study are designed as follows:

Assessment: The systematic process of gathering specific evidence of what a student accomplishes. Its principal function in schools is to provide diagnostic information, formal or informal, about pupils' abilities and levels of attainment.

Working Papers in Art Education 1992 
Evaluation: Defined as a more general process than assessment, evaluation looks beyond diagnosis to the overall considerations of teaching and learning. Bloom et al. (1971) define evaluation as:

the making of judgements about the value, for some purpose, of ideas, works, solutions, methods, materials, etc. It involves the use of criteria as well as standards for appraising the extent to which particulars are accurate, effective, economical or satisfying. The judgements may be either quantitative or qualttative, and criteria may be those ether determined by the student or those which are given to him. (p. 63)

Art Teachers: Refers to teachers at all grade levels who teach art education to students in public schools.

Art Specialists: Refers to those teachers who have a strong and extensive academic or experience-based background in art education.

\section{The Research Problem}

Teacher defined criteria are the basis for conducting student assessment in art, although the issues are somewhat different in elementary and secondary programs. In elementary schools there are few specialists, and the majority of the art teachers are teaching and assessing student performance in art programs with little expertise or formal training in art education. The dictum "one cannot make judgements from ignorance" applies as fully to this segment of educational programming as it does to other school subjects.

In secondary schools, there are proportionately more specialist teachers with expertise and training in the subject. Also, the elective nature of the school programs may encourage better performance simply due to the element of students' choice. However, no consistency of performance expectations, particularly through the collaboration of professional thinking and action, is established in the support materials available to these teachers.

Currently, assessment in art education is an internal matter conducted by the classroom teacher. The key issue in assessing a student's ant work is the professional judgement of the teacher involved: assessment in art education depends upon teacher characteristics and teacher practice. Therefore, to add to the knowledge base of the art assessment strategies and criteria employed by teachers, they will need data about their classroom practice.

What formative influences and educational assumptions are reflected in the art assessment practices of teachers? Without the knowledge of what might constitute art assessment criteria for teachers, practices can be neither supported nor refuted. 
Therefore, two important questions guide this study; they are in effect the research questions:

1) What are the characteristics of art teachers that determine their art assessment criteria and practices?

2) What are the relationships between teachers' belief systems and the characteristics of experience, confidence and expertise?

At least three kinds of teacher states may be examined, to show differences among individuals and common attitudes or perspectives. The first is experience: time spent in the classroom brings familiarity. The second is confidence: in one's subject and in one's teaching. The third is expertise: technical skills and interpretive ability.

\section{Rationale and Justification for the Study}

Collecting descriptive information on teachers' present assessment practices in art education in Alberta public schools appears to be a necessary response to the rise of alternative assessment strategies avallable to teachers. The literature reviewed suggests that teachers' philosophical beliefs play a primary role in art assessment; their practices are contingent on how they view art assessment for students (Chapman, 1979).

The notion that teachers' art assessment strategies are based on ind lvidual interpretation has far-reaching implications and must be taken seriously, especially at the secondary levels (in the Province of Alberta), where art is a university entrance subject. The dynamics of assessment in art are complex and require that appropriate resources be developed and personnel adequately trained, so that assessment procedures are appropriate to the proposed learning experience.

Case studies and correlational survey data of teachers engaged in art assessment in different school settings may provide understanding of why the present criteria are used. Justification for this study has been derived from a review of literature that posits a need to build on the theory of Eisner and others that art assessment is an essential component of art learning for students (Brandt, R. 1987; Day, M. 1985; Saunders, R. 1986; Wolf, D. 1986).

Conclusions in the literature are that teachers practical knowledge can be better understood by studying teachers in their environments (Connelly, M. \& Clandinin, J. 1988; Wolcott, 1982; Spradley, J. P. 1989; Rafferty, P. 1987). New insights may be gained that will result in teacher art assessment resources and teacher change through implementation offered by school districts' subject area specialists or by education ministries.

The limited studies in the literature reviewed did not examine teachers' art assessment in depth or as an ongoing process. Use of a survey

Working Papers in Art Education 1992 
instrument and a case study format employing ethnographic tools can perform this examination by providing detailed description of art teachers' assessment practices. From these accounts, concepts or theoretical explanations may be learned of what teachers' present art assessment practices are. By these means, it will become possible to determine what rationales guide their practices. The problem is not the practice of art assessment by teachers, since they presently fulfill this function, but with the lack of information about how this function is conducted. Are teachers' art assessment criteria idiosyncratic, or based on common shared beliefs, academic backgrounds or external measures?

\section{Research Design}

The research will employ both qualitative and naturalistic inquiry methods. Each type of data offers unique strengths to the study. The use of both research methods is consistent with the concept of triangulation, whereby multiple data sources and/or multiple measures are used to increase the credibility of the information and the understanding of phenomena. Similarly, triangulation is broadly defined by Denzin (1978) as "the combination of methodologies in the study of the same phenomenon" (p. 291). This mode of research strategy is also advocated and defined as multi-method convergent methodology, (Campbell \& Fiske, 1959) and convergent validation (Webb et al, 1966). Their rationale for use of these methods is to increase the credibility of the data and the understanding of phenomena.

Data will be gathered in June, 1992, using an art teacher survey instrument at the grade $2,5,8$, and 11 levels $(n=900)$ and a longitudinal (September, 1992 to June, 1993) multi-site case study format employing ethnographic techniques: classroom non-participant and participant observations, interviews and teacher joumal writing. Collected data, when combined, may form a picture that yields insights into teachers' criteria and strategies for art assessment. Collected data of possible similar and dissimilar assessment practices followed by analyses will be used for the construction of a taxonomy.

\section{References}

Bloom, B. (1971). Handbook of formative and summative evaluation of students' leaming. Toronto: McGraw Hill

Bullough, R. V., \& Goldstein, S. L (1984). Technical curriculum from an American elementary school art education. Journal of Curriculum Studies, 16 (2), 143-154.

Brandt, R. (1987). An assessment in the arts: A conversation with Howard Gardner. Educational Leadership, 25 (4). 
Campbell, D. T. \& Fiske, D. W. (1959). Convergent and discriminant valisation by the multitriat-multimethod matrix. Psychological Bulletin, 56, 81-105.

Chapman, L. (1978). Approaches to art in education. New York: Harcourt, Brace \& Jovanich.

Chapman, L. (1979). The bearbug of artistic and educational commitments on the teaching of art. In G. L. Knieter \& Stallings, J. (Eds.), The Teaching Process \& Arts and Aesthetic. St. Louis, Missouri: CEMREL.

Connelly, M. \& Clandinin, J. (1988). Teachers as curriculum planners. Teachers College: Columbia University.

Day, M. D. (1985). Evaluating student achievement in discipline-based art programs. Studies in Art Education, 26 (4), 232-240.

Denzin, N. K. (1978). The research act: A theoretical introduction to sociological methods (2nd ed.). Chicago: Aldine.

Eisner, E. W. (1988). Discipline-based art education: Its criticism and its critics. Art Education, 45 (6).

Getty Foundation For Education in the Arts, (1985). Beyond creating: The place for art in America's schools. Los Angeles: Paul Getty Trust.

Greer, W. D. (1984). Discipline-based art education: Approaching art as a subject of study. Studies in Art Education, 25 (4), 221-228.

Greer, W. D., \& Hoepfner, R. (1986). Achieving testing in visual arts. Design for Arts in Education, 88 (1), 43-48.

Hamblen, K. A. (1986). Testing in art: A view from the classroom. Design for Arts in Education, 88 (1), 12=17.

(1988). If it is to be tested, it will be taught: A rationale worthy of examination. Art Education, 41 (5), 59-62.

Lehman, P. R. (1986). A balance testing program includes the arts. Design for Arts in Education, 88 (1), 36.

Rafferty, R. (1987). An Interpretive Study of Elementary School Teachers' Descriptive Accounts of the Art Teaching Task. Unpublished doctoral dissertation, University of British Columbia.

Saunders, R. J. (1986). Testing in elementary school art for growth and grades. Design for Arts in Education, 88 (1), 48-51. 
Spradley, J. P. (1989). Participant observer. New York: Holt Rinehart.

Webb, E. J., et al, (1966). Unobtrusive measures: Non-reactive research in the social sciences. Chicago: Rand Nally.

Wilson, B. (1986). Testing and the process of change. Design for Arts in Education, 88 (1), 7.

Wolcott, H. F. (1982). Doing the ethnography of schooling. New York: Holt, Rhinehart \& Winston.

Wolf, D. (1986). Portfolio assessment: Sampling student art work. Educational Leadership, 47 (7), 35-39. 